\title{
ESTIMASI NILAI PEMULIAAN DAN MOST PROBABLE PRODUCING ABILITY SIFAT PRODUKSI SAPI ACEH DI KECAMATAN INDRAPURI PROVINSI ACEH
}

\section{THE ESTIMATION OF BREEDING VALUE AND MOST PROBABLE PRODUCING ABILITY OF PRODUCTION TRAITS ACEH CATTLE AT INDRAPURI DISTRICT ACEH PROVINCE}

\author{
Widya Pintaka Bayu Putra*, Sumadi, dan Tety Hartatik \\ Fakultas Peternakan, Universitas Gadjah Mada, Jl. Fauna No. 3, Bulaksumur, Yogyakarta, 55281
}

\section{INTISARI}

Penelitian ini bertujuan untuk membuat estimasi nilai pemuliaan (NP) dan most probable producing ability (MPPA) sifat produksi sapi Aceh di Kecamatan Indrapuri, Provinsi Aceh. Penelitian dilaksanakan mulai tanggal 7 Maret 2013 sampai dengan 7 April 2013 di Balai Pembibitan Ternak Unggul (BPTU)-Hijauan Pakan Ternak (HPT) Sapi Aceh Indrapuri. Materi penelitian ini terdiri dari catatan produksi dan populasi sapi Aceh tahun 2010 sampai 2012. Jumlah sapi yang digunakan untuk mengestimasi NP dan MPPA pada sifat produksi adalah 38 ekor. Estimasi nilai estimasi heritabilitas dengan metode korelasi saudara tiri sebapak (paternal half-shib correlation), sedangkan estimasi repitabilitas berdasarkan dua catatan individu menggunakan metode korelasi antar kelas (interclass correlation). Hasil penelitian menunjukkan bahwa nilai heritabilitas berat lahir, berat sapih, berat satu tahun, dan berat akhir masingmasing adalah $0,15 \pm 0,12,0,48 \pm 0,58,0,49 \pm 0,58$, dan $0,56 \pm 0,69$. Nilai repitabilitas yang dapat diestimasi berdasarkan data recording adalah berat lahir sebesar $0,33 \pm 0,22$. Sapi Aceh pejantan nomor P. 075 memiliki $\mathrm{NP}_{\text {absolut }}$ berat akhir tertinggi yaitu sebesar $14,99 \mathrm{~kg}$. Nilai $\mathrm{MPPA}_{\text {absolut }}$ berat lahir tertinggi pada induk sapi Aceh nomor A.0668 yaitu sebesar $15,38 \mathrm{~kg}$.

(Kata kunci: Sapi Aceh, NP, MPPA, Heritabilitas, Repitabilitas, Sifat produksi)

\section{ABSTRACT}

This research was conducted to estimate the breeding value (BV) and most probable producing ability (MPPA) of production traits Aceh cattle at Indrapuri Breeding and Forages Centre of Aceh Cattle, Indrapuri district, Aceh Province. The research was done from March 7, 2013 to April 7, 2013. Data consisted of production and population records collected from 2010 to 2012. Total cattle that used to BV and MPPA of production traits were 38 heads of cattle. Heritability value was analyzed by paternal half-ship correlation, whereas repeatability was estimated based on two individual records using interclass correlation. The results indicated that heritability value of birth weight, weaning weight, yearling weight and final weight were $0.15 \pm 0.13 ; 0.48 \pm 0.58 ; 0.49 \pm 0.58$ and $0.56 \pm 0.69$ respectively. The estimated repeatability estimate based on records were on birth weight: $0.33 \pm 0.22$. The highest $B V_{\text {absolute }}$ of birth weight were on Aceh cattle bull number P.075 $(14.99 \mathrm{~kg})$. The highest MPPA absolute of birth weight were on Aceh cattle cow number A.0668 (15.38 kg).

(Key words: Aceh cattle, BV, MPPA, Heritability, Repeatability, Production traits)

\section{Pendahuluan}

Daging sapi merupakan sumber protein hewani yang penting bagi masyarakat namun pengadaan suplai bibit unggul di Indonesia masih kurang. Kebutuhan daging sapi sebagai salah satu sumber protein hewani akan terus meningkat sejalan dengan adanya peningkatan kesadaran masyarakat terhadap pentingnya gizi, pertambahan jumlah penduduk, dan peningkatan daya beli masyarakat. Populasi sapi potong di Indonesia tahun 2012 diperkirakan mencapai 16.034.336 ekor dan sekitar $3 \%$ dari total populasi atau 483.628 ekor terdapat di Provinsi Aceh (Anonimus, 2012). Produksi daging

\footnotetext{
* Korespondensi (corresponding author):

Telp. +62 8122693303

E-mail: banchet_putra18@yahoo.co.id
}

di Provinsi Aceh pada tahun 2007 sebesar $5.277 .864 \mathrm{~kg}$ sedangkan konsumsi masyarakat di wilayah itu mencapai $6.877 .800 \mathrm{~kg}$ sehingga provinsi ini mengalami kekurangan daging sebanyak 1.599.936 kg (Saputra et al., 2011).

Kebutuhan daging di Provinsi Aceh dapat dicukupi melalui peningkatan populasi dan produktivitas sapi Aceh yang telah lama beradaptasi dengan lingkungan di Aceh. Sapi Aceh ditetapkan sebagai salah satu rumpun sapi asli Indonesia pada tahun 2011 melalui Keputusan Menteri Pertanian Republik Indonesia No: 2907/Kpts/OT.140/6/2011 (Anonimus, 2012). Sapi Aceh memiliki daya tahan terhadap kondisi lingkungan yang buruk seperti krisis pakan, air, pakan berserat tinggi, penyakit parasit, temperatur panas, dan sistem pemeliharaan 
ekstensif tradisional (Gunawan et al., 1998). Salah satu cara untuk meningkatkan produktivitas sapi Aceh adalah melalui seleksi ternak dengan menggunakan pejantan dan betina yang unggul. Potensi genetik seekor pejantan, calon pejantan, dan calon induk dapat diestimasi dengan nilai pemuliaan (NP). Produktivitas induk dan kemampuan mengasuh anak (mothering ability) dapat diukur dengan mengestimasi most probable producing ability (MPPA). Suatu ternak yang memiliki NP dan MPPA yang tinggi berarti ternak tersebut memiliki produktivitas yang tinggi dan dapat diwariskan pada keturunannya (Hardjosubroto, 1994).

Berat lahir yang tinggi cenderung akan meningkatkan berat sapih dan pertumbuhan lepas sapih. Semakin tinggi berat lahir ternak cenderung akan meningkatkan daya tahan dan daya hidup yang lebih kuat. Berat sapih juga berkorelasi positif dengan berat satu tahun. Berat sapih sering dipakai untuk kriteria seleksi karena berdasarkan berat sapih secara tidak langsung induk juga dapat diseleksi (Hardjosubroto, 1994). Induk yang memiliki ratarata berat sapih keturunan yang tinggi juga akan memiliki nilai MPPA yang tinggi serta memiliki sifat mothering ability yang baik (Falconer dan Mackay, 1996).

Balai Pembibitan Ternak Unggul (BPTU)Hijauan Pakan Ternak (HPT) Sapi Aceh Indrapuri memiliki tugas melaksanakan pemuliaan, produksi, dan pemasaran bibit sapi Aceh yang unggul. Sejak pertama berdiri tahun 1978 BPTU-HPT Sapi Aceh belum pernah melakukan seleksi ternak berdasarkan NP dan MPPA. Seleksi ternak untuk replacement pada saat itu hanya berdasarkan karakteristik eksterior, ukuran tubuh, dan berat badan. Kegiatan recording untuk pemuliaan ternak di BPTU-HPT Sapi Aceh sudah dimulai sejak tahun 2010 sampai sekarang, sehingga data recording yang diperoleh untuk mengestimasi NP pejantan dan MPPA induk hanya pada berat lahir saja. Hasil penelitian ini diharapkan dapat bermanfaat khususnya bagi BPTU-HPT Sapi Aceh sebagai dasar seleksi ternak untuk meningkatkan produktivitas sapi Aceh.

\section{Materi dan Metode}

Penelitian dilaksanakan di BPTU-HPT Sapi Aceh Indrapuri Provinsi Aceh mulai 7 Maret 2013 sampai 7 April 2013. Materi yang digunakan berupa data primer yaitu catatan produksi dan populasi sapi dari tahun 2010 sampai 2012. Sebanyak 38 ekor sapi yang terdiri dari pejantan 8 ekor, induk 10 ekor, calon pejantan 10 ekor, dan calon induk 10 ekor digunakan untuk estimasi NP dan MPPA. Data berat lahir dan berat sapih dikoreksi terhadap jenis kelamin dan umur induk. Berat sapih, berat satu tahun dan berat akhir masing-masing dikoreksi terhadap umur 205 hari, 365 hari, dan 550 hari (Hardjosubroto, 1994).

Rumus yang digunakan untuk memperoleh berat badan terkoreksi dilakukan menurut rekomendasi Hardjosubroto (1994) sebagai berikut:

$$
\mathrm{BL}_{\mathrm{T}}=\mathrm{BL} \times \mathrm{FKJK} \times \mathrm{FKUI}
$$

$$
\begin{aligned}
& \mathrm{FKJK}_{\text {betina }}=\frac{\text { Rerata BL jantan }}{\text { Rerata BL betina }} \\
& \mathrm{BS}_{\mathrm{T}}=\left(\frac{\mathrm{BS}-\mathrm{BL}}{\text { umur }} \times 205+\mathrm{BL}\right) \times(\mathrm{FKUI}) \times(\mathrm{FKJK}) \\
& \mathrm{BY}_{\mathrm{T}}=\frac{\mathrm{BY}-\mathrm{BS}}{\text { tenggang waktu }} \times 160+\mathrm{BS}_{\mathrm{T}} \\
& \mathrm{BA}_{\mathrm{T}}=\frac{\mathrm{BA}-\mathrm{BS}}{\text { tenggang waktu }} \times 345+\mathrm{BS}_{\mathrm{T}}
\end{aligned}
$$

Untuk mengestimasi NP dan MPPA berat lahir diperlukan informasi nilai heritabilitas dan repitabilitas berat lahir. Rumus heritabilitas $\left(h^{2}\right)$ yang diestimasi dengan metode korelasi saudara tiri sebapak sesuai petunjuk Becker (1992) sebagai berikut:

$$
\mathrm{h}^{2}=\frac{4 \sigma_{S}^{2}}{\sigma_{S}^{2}+\sigma_{W}^{2}}
$$

Metode estimasi heritabilitas dengan metode korelasi saudara tiri sebapak merupakan metode yang terbaik, karena tidak mengandung ragam dominan dan tidak ada pengaruh induk. Pengaruh induk dapat membuat hasil estimasi heritabilitas menjadi terlalu tinggi (Falconer dan Mackay, 1996). Rumus repitabilitas (r) pada suatu sifat diestimasi dengan metode korelasi antar kelas (interclass correlation) berdasarkan pada dua catatan individu sesuai petunjuk Warwick et al. (1990) sebagai berikut:

$$
r=\frac{\sum X_{1} X_{2}-\frac{\sum x_{1} \sum x_{2}}{N}}{\sqrt{\left(\sum x_{1}-\frac{\left(\sum x_{1}\right)^{2}}{N}\right)-\left(\sum x_{2}-\frac{\left(\sum x_{2}\right)}{N}\right)}}
$$

Rumus NP diestimasi sesuai petunjuk Hardjosubroto (1994) adalah sebagai berikut:

Nilai pemuliaan pejantan

$$
\begin{aligned}
& N P_{\text {absolut }}=\frac{n h^{2}}{1+(n-1) r}(\bar{P}-\overline{\bar{P}})+\overline{\bar{P}} \\
& N P_{\text {relatif }}=\frac{n h^{2}}{1+(n-1) r}(\bar{P}-\overline{\bar{P}})
\end{aligned}
$$


Nilai pemuliaan calon pejantan dan calon induk

$$
N P_{\text {relatif }}=h^{2}(\bar{P}-\overline{\bar{P}}) \quad \text { dan } \quad N P_{\text {absolut }}=h^{2}(\bar{P}-\overline{\bar{P}})+\overline{\bar{P}}
$$

Rumus MPPA induk diestimasi sesuai petunjuk Hardjosubroto (1994) sebagai berikut:

$$
\begin{aligned}
& M P P A_{\text {absolut }}=\frac{n r}{1+(n-1) r}(\bar{P}-\overline{\bar{P}})+\overline{\bar{P}} \\
& M P P A_{\text {relatif }}=\frac{n r}{1+(n-1) r}(\bar{P}-\overline{\bar{P}})
\end{aligned}
$$

Keterangan:

$\mathrm{BL}_{\mathrm{T}}=$ berat lahir terkoreksi

$\mathrm{BL}=$ berat lahir sebenarnya

$\mathrm{BS}_{\mathrm{T}}=$ berat sapih terkoreksi (205 hari)

$\mathrm{BS}=$ berat sapih

$\mathrm{BY}_{\mathrm{T}}=$ berat yearling terkoreksi (365 hari)

$\mathrm{BY}=$ berat yearling sebenarnya

$\mathrm{BA}_{\mathrm{T}}=$ berat akhir terkoreksi (550 hari)

$\mathrm{BA}=$ berat akhir sebenarnya

FKJK $=$ faktor koreksi jenis kelamin

FKUI $=$ faktor koreksi umur induk

$\mathrm{X}_{1}=$ catatan berat lahir pertama

$\mathrm{X}_{2}=$ catatan berat lahir kedua

$\mathrm{N} \quad=$ jumlah individu

$\mathrm{n} \quad=$ jumlah anak

$\mathrm{h}^{2}=$ heritabilitas

$\mathrm{r} \quad=$ repitabilitas

$\bar{P} \quad=$ rata-rata berat badan anak per pejantan/induk

$\overline{\bar{P}} \quad=$ rata-rata berat badan populasi

$\sigma_{S}^{2} \quad=$ komponen ragam antar pejantan

$\sigma_{W}^{2}=$ komponen ragam antar individu

\section{Hasil dan Pembahasan}

\section{Heritabilitas}

Estimasi nilai heritabilitas diperlukan untuk menghitung NP. Hasil estimasi nilai heritabilitas sifat produksi sapi Aceh dengan metode korelasi saudara tiri sebapak (paternal half-shib correlation) disajikan pada Tabel 1. Nilai heritabilitas berat lahir (BL) yang diperoleh termasuk handal karena memiliki nilai SE yang lebih rendah dari nilai heritabilitas. Tingginya nilai standard error (SE) pada penelitian ini disebabkan karena jumlah sampel (anak) dan pejantan (sire) diestimasi sedikit dan adanya variasi fenotip antar individu besar. Diperlukan jumlah sampel minimal 500 sampel agar nilai heritabilitas yang diperoleh handal (Warwick et al., 1990).
Nilai heritabilitas pada penelitian ini dihitung berdasarkan asumsi sapi-sapi yang diestimasi tersebut mendapat pakan, pemeliharaan, dan lingkungan yang sama, sehingga mutu genetik ternak dapat diukur. Nilai heritabilitas BL sebesar 0,15 menunjukkan bahwa keragaman BL pada populasi $15 \%$ dipengaruhi oleh faktor ragam genetik dari tetuanya.

Hasil estimasi heritabilitas sifat produksi pada sapi Simmental oleh Suhada et al. (2009) antara lain BL termasuk kategori sedang $(0,11 \pm 0,09)$, berat sapih (BS) dan berat yearling (BY) termasuk kategori tinggi masing-masing $0,39 \pm 0,16$ dan $0,43 \pm 0,19$ sama seperti pada penelitian ini. Hasil penelitian lainnya pada sapi Brahman Cross oleh Gushairiyanto dan Depison (2009) menunjukkan bahwa nilai heritabilitas BS dan BY juga termasuk kategori yang tinggi $(0,62 \pm 0,40$ dan $1,05 \pm 0,59)$. Perbedaan nilai heritabilitas pada beberapa penelitian tersebut disebabkan karena heritabilitas bukan merupakan konstanta dan bergantung pada jumlah populasi, waktu estimasi, dan bangsa ternak (Lasley, 1978; Chapman, 1985).

\section{Repitabilitas}

Estimasi nilai repitabilitas diperlukan untuk menghitung MPPA. Nilai repitabilitas sifat produksi yang dapat diestimasi pada penelitian berdasarkan data recording yang diperoleh adalah BL. Estimasi repitabilitas berat lahir terkoreksi $\left(\mathrm{BL}_{\mathrm{T}}\right)$ sapi Aceh adalah $0,36 \pm 0,21$. Nilai repitabilitas BL yang tinggi menunjukkan bahwa kelompok induk di lokasi penelitian memiliki kemampuan untuk mengulangi prestasinya dalam menghasilkan anak dengan $\mathrm{BL}$ yang hampir sama dengan berat lahir sebelumnya (Cunningham, 1969).

Repitabilitas BL yang diestimasi pada penelitian ini terdiri dari 10 ekor induk sapi Aceh yang masing-masing memiliki dua catatan BL keturunannya. Nilai repitabilitas BL termasuk handal karena memiliki nilai SE yang rendah. Sapi Simmental memiliki nilai repitabilitas BL sebesar 0,25 $\pm 0,16$ termasuk kategori sedang (Suhada et al., 2009) sama seperti pada sapi Hereford yaitu 0,27 $\pm 0,02$ (Kress dan Buferning, 1972). Perbedaan hasil estimasi repitabilitas BL dari penelitian sebelumnya disebabkan oleh perbedaan jumlah dan lokasi populasi, waktu saat dilakukan estimasi, dan breed sapi yang berbeda (Pattie dan James, 1985). Secara teoritis nilai repitabilitas selalu lebih besar dari nilai heritabilitas karena pengaruh ragam genetik dan lingkungan yang diterima oleh seekor induk (Warwick et al., 1990) sama seperti pada penelitian ini bahwa $\mathrm{BL}_{\mathrm{T}}$ memiliki nilai repitabilitas yang lebih besar dibanding heritabilitas. 


\section{Nilai pemuliaan (NP)}

Estimasi NP pejantan. Estimasi NP sifat produksi yang dapat diestimasi hanya pada sifat BL karena nilai repitabilitas yang dapat diestimasi juga hanya pada sifat BL. Estimasi NP sifat BL pada delapan pejantan sapi Aceh tersaji pada Tabel 2. Pejantan sapi Aceh yang memiliki $\mathrm{NP}_{\text {relatif }} \mathrm{BL}_{\mathrm{T}}$ negatif berarti rata-rata $\mathrm{BL}$ keturunannya berada di bawah rata-rata populasinya. Tabel 2 terlihat bahwa terdapat beberapa pejantan yang memiliki $\mathrm{NP}_{\text {absolut }}$ berat lahir yang sama. Uji Zuriat tahun 1991-1993 pada tiga pejantan sapi Madura yang dilakukan oleh Sub Balai Penelitian Ternak Grati Jawa Timur juga menghasilkan $\mathrm{NP}_{\text {relatif }}$ yang sama yaitu sekitar $15,00 \mathrm{~kg}$ (Yusran et al., 1995). Penggunaan BL sebagai dasar seleksi ternak memiliki ketepatan prediksi yang rendah (Lasley, 1978) yang ditunjukkan dengan peringkat ranking NP yang sama pada pejantan yang diestimasi. Penggunaan pejantan dalam program breeding di BPTU-HPT Sapi Aceh adalah sekitar sembilan tahun. Setiap pejantan ditempatkan di kandang breeding selama satu tahun untuk mengawini 20 betina. Menurut Daly (1980), lama penggunaan pejantan dalam breeding adalah dua sampai tiga tahun. Penggunaan pejantan yang terlalu lama dapat menyebabkan keragaman genetik suatu sifat antar individu menjadi kecil sehingga seleksi pada sifat produksi menjadi kurang efektif (Daniel, 1980). Sapi pejantan nomor P.075 memiliki nilai $\mathrm{NP}_{\text {relatif }}$ $\mathrm{BL}_{\mathrm{T}}$ tertinggi yaitu 0,42 yang berarti bahwa keunggulan anak-anak pejantan P.075 secara relatif sebesar $0,42 \mathrm{~kg}$ di atas rata-rata populasi. Penggunaan pejantan P.075 diharapkan dapat meningkatkan rata-rata performan BL sebesar 14,99 $\mathrm{kg}$ lebih tinggi dibanding BL populasi sebesar 14,57 $\mathrm{kg}$.

Estimasi NP calon pejantan. Untuk memilih calon pejantan sapi Aceh juga digunakan estimasi NP sebagai dasar seleksi ternak. Seleksi calon pejantan di lokasi penelitian dilakukan pada umur dua tahun (550 hari). Hasil estimasi NP pada 10 ekor calon pejantan sapi Aceh terbaik disajikan pada Tabel 3. Calon pejantan sapi Aceh yang memiliki NP tertinggi merupakan sapi terbaik sehingga digunakan sebagai pejantan. Beberapa pejantan sapi Aceh yang memiliki NP di atas ratarata NP kelompoknya digunakan untuk replacement atau pengganti sapi pejantan yang sudah tua. Dari Tabel 3 terlihat bahwa terdapat beberapa sapi Aceh memiliki perubahan ranking pada setiap kelompok berat badan. Performan ternak dapat berubah karena

Tabel 1. Estimasi heritabilitas sifat produksi dan standard error sapi Aceh di BPTU-HPT Sapi Aceh Indrapuri (heritability estimation of production traits and standard error on Aceh cattle at BPTU-HPT Sapi Aceh Indrapuri)

\begin{tabular}{lcccl}
\hline \hline Sifat produksi (production trait) & $\begin{array}{c}\text { Jumlah } \\
\text { pejantan (total } \\
\text { of sire) }\end{array}$ & $\begin{array}{c}\text { Jumlah anak } \\
\text { (total of } \\
\text { progeny) }\end{array}$ & $\mathrm{h}^{2} \pm \mathrm{SE}$ & Kategori (category) \\
\hline Berat lahir (birth weight) & 9 & 171 & $0,15 \pm 0,13$ & Sedang (moderate) \\
Berat sapih (weaning weight) & 4 & 48 & $0,48 \pm 0,58$ & Tinggi (high) \\
Berat 1 tahun (yearling weight) & 4 & 48 & $0,49 \pm 0,58$ & Tinggi (high) \\
Berat akhir (final weight) & 4 & 48 & $0,56 \pm 0,69$ & Tinggi (high) \\
\hline
\end{tabular}

Tabel 2. Nilai pemuliaan berat lahir terkoreksi pada pejantan sapi Aceh di BPTU-HPT Sapi Aceh Indrapuri (breeding value estimation of corrected birth weight on Aceh cattle bulls at BPTU-HPT Sapi Aceh Indrapuri)

\begin{tabular}{|c|c|c|c|c|c|}
\hline $\begin{array}{l}\text { Peringkat } \\
\text { (ranking) }\end{array}$ & $\begin{array}{l}\text { Nomor pejantan } \\
\text { (number of bull) }\end{array}$ & $\begin{array}{c}\text { Jumlah anak } \\
\text { (total of progeny) }\end{array}$ & $\begin{array}{c}\text { Rata-rata } \mathrm{BL}_{\mathrm{T}} \text { anak }(\mathrm{kg}) \\
\text { (average of } B W_{C} \\
\text { progeny }(\mathrm{kg}) \text { ) }\end{array}$ & $\begin{array}{l}\mathrm{NP}_{\text {relatif }}(\mathrm{kg}) \\
\left(B V_{\text {relative }}(\mathrm{kg})\right)\end{array}$ & $\begin{array}{c}\mathrm{NP}_{\text {absolut }}(\mathrm{kg}) \\
\left(B V_{\text {absolute }}(\mathrm{kg})\right)\end{array}$ \\
\hline 1 & P.075 & 50 & 15,62 & 0,42 & 14,99 \\
\hline 2 & G.005 & 20 & 15,64 & 0,41 & 14,98 \\
\hline 3 & P.0753 & 19 & 15,30 & 0,28 & 14,85 \\
\hline 4 & P.0752 & 73 & 14,94 & 0,15 & 14,72 \\
\hline 5 & А.0209 & 25 & 14,83 & 0,10 & 14,67 \\
\hline 6 & А.001 & 41 & 13,57 & $-0,40$ & 14,17 \\
\hline 7 & P.0751 & 25 & 13,41 & $-0,45$ & 14,12 \\
\hline \multirow[t]{2}{*}{8} & A.004 & 33 & 13,25 & $-0,52$ & 14,05 \\
\hline & Rata-rata $\mathrm{BL}_{\mathrm{T}}(\mathrm{av}$ & verage of $\left.B W_{C}\right)$ & $14,57 \pm 1,00$ & & \\
\hline
\end{tabular}

NP: nilai pemuliaan (BV: breeding value), $\mathrm{BL}_{\mathrm{T}}$ : berat lahir terkoreksi $\left(B W_{C}\right.$ : corrected birth weight). 
:

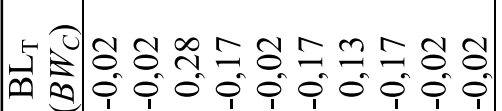
可

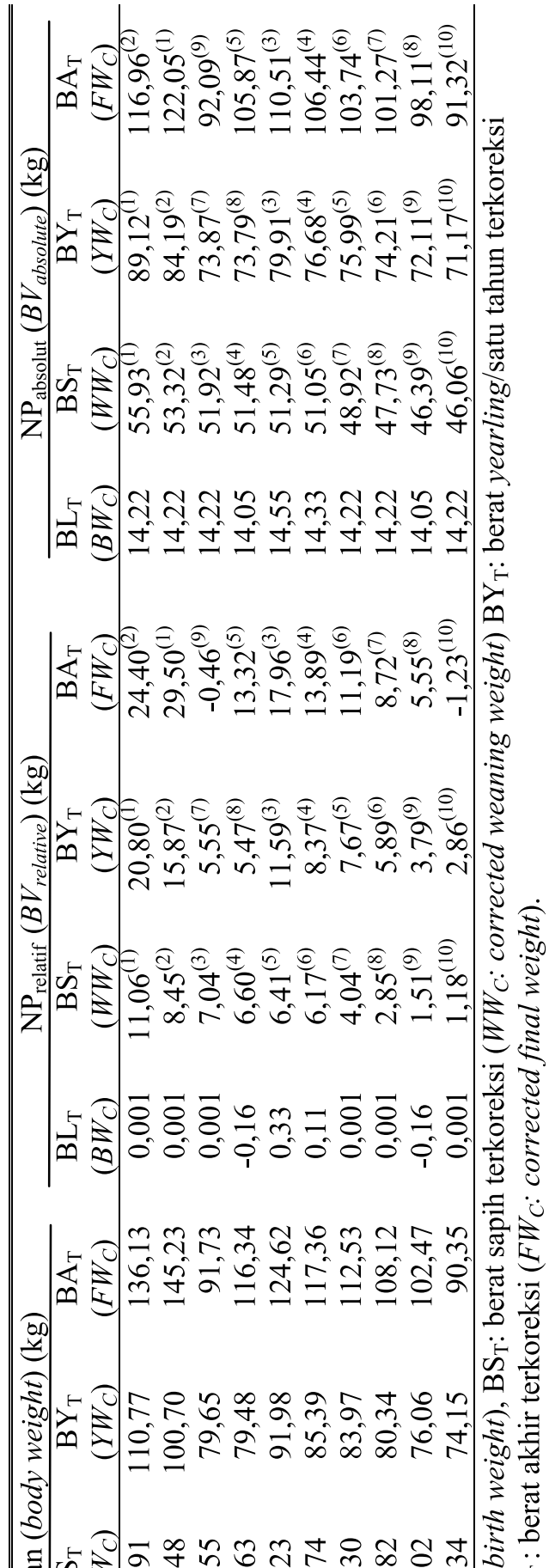

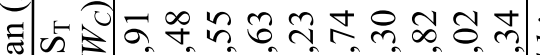

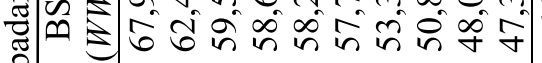

莺

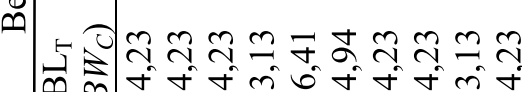

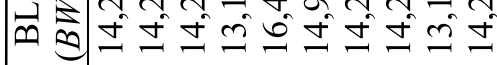

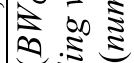
ำ

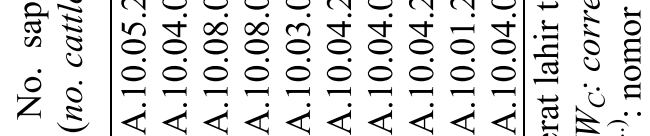
焉 
Tabel 5. Nilai MPPA berat lahir terkoreksi pada induk sapi Aceh di BPTU-HPT Sapi Aceh Indrapuri berdasarkan dua catatan individu (the MPPA value of corrected birth weight on Aceh cattle cows at BPTU-HPT Sapi Aceh Indrapuri based on two individual records)

\begin{tabular}{clccc}
\hline \hline $\begin{array}{c}\text { Peringkat } \\
\text { (ranking) }\end{array}$ & $\begin{array}{c}\text { Nomor induk } \\
(\text { number of dam })\end{array}$ & $\begin{array}{c}\text { Rata-rata } \mathrm{BL}_{\mathrm{T}} \text { anak }(\mathrm{kg}) \\
\left.\text { average of } B W_{C} \text { progeny }(\mathrm{kg})\right)\end{array}$ & $\begin{array}{c}\mathrm{NP}_{\text {relatif }}(\mathrm{kg}) \\
\left(B V_{\text {relative }}(\mathrm{kg})\right)\end{array}$ & $\begin{array}{c}\mathrm{NP}_{\text {absolut }}(\mathrm{kg}) \\
\left(B V_{\text {absolute }}(\mathrm{kg})\right)\end{array}$ \\
\hline 1 & A.0668 & 17,00 & 1,38 & 15,78 \\
2 & A.670 & 16,50 & 1,11 & 15,51 \\
3 & A.200 & 16,00 & 0,85 & 15,25 \\
4 & A.0643 & 15,00 & 0,32 & 14,72 \\
5 & A.0619 & 15,50 & 0,58 & 14,58 \\
6 & A.95 & 14,50 & 0,05 & 14,45 \\
7 & A.0658 & 14,00 & $-0,21$ & 14,19 \\
8 & A.215 & 13,50 & $-0,48$ & 13,92 \\
9 & 1261 & 13,00 & $-0,74$ & 13,66 \\
10 & A.11 & 12,50 & $-1,01$ & 13,39 \\
& Rata-rata (average) & $14,75+1,51$ & & \\
\hline
\end{tabular}

MPPA: most probable producing ability, NP: nilai pemuliaan (BV: breeding value), $\mathrm{BL}_{\mathrm{T}}$ : berat lahir terkoreksi $\left(B W_{C}:\right.$ corrected birth weight).

faktor lingkungan antara lain pakan, kesehatan, dan iklim (Hammond dan Upton, 1985). Sistem pemeliharaan sapi Aceh di lokasi penelitian adalah secara ekstensif sehingga sangat bergantung pada ketersediaan hijauan (forage) di padang pangonan (pasture).

Estimasi NP calon induk. Seleksi pada calon induk juga berdasarkan pada NP. Sapi betina calon induk mulai diseleksi pada umur sekitar dua tahun. Semua sapi yang akan digunakan pada program breeding harus memenuhi syarat kualitatif (ciri eksterior) dan kuantitatif (ukuran tubuh dan berat badan). Selain itu semua sapi yang digunakan pada program breeding harus terbebas dari cacat fisik (Supiyono, 1998). Sapi betina (heifer) yang terpilih digunakan sebagai pengganti induk yang sudah tua atau mengalami gangguan reproduksi. Nilai pemuliaan pada 10 ekor calon induk sapi Aceh disajikan pada Tabel 4. Berdasarkan pada tabel tersebut terlihat bahwa sebagian besar sapi betina memiliki ranking yang berbeda pada setiap periode berat badan. Kondisi lingkungan berubah-ubah saat sapi disapih sampai dewasa menyebabkan performan sapi juga ikut berubah. Seleksi ternak dapat dilakukan pada heifer yang memiliki NP di bawah rata-rata populasinya.

\section{Most probable producing ability (MPPA)}

Daya produksi induk atau MPPA merupakan gambaran potensi berproduksi setiap induk dalam suatu populasi tertentu. Rata-rata berat sapih anak yang tinggi ditunjukkan dengan nilai MPPA berat sapih yang tinggi (Hardjosubroto, 1994). Estimasi nilai MPPA pada penelitian ini hanya dapat dilakukan pada sifat $\mathrm{BL}_{\mathrm{T}}$ karena data recording ternak yang diperoleh tidak lengkap. Estimasi nilai MPPA berat lahir dari 10 ekor induk (cow) di
BPTU-HPT Sapi Aceh Indrapuri tersaji pada Tabel 5. Hasil estimasi MPPA pada $\mathrm{BL}_{\mathrm{T}}$ dari dua catatan individu menunjukkan bahwa terdapat empat ekor induk yang memiliki nilai MPPA $_{\text {relatif }}$ negatif (A.0658, A.215, 1261, dan A.11). Culling pada BL terhadap induk saat ini jarang dilakukan karena seleksi terhadap BL secara terus-menerus dapat menyebabkan kesukaran melahirkan (dystochia). Selain itu seleksi pada BL belum bisa menggambarkan kemampuan mengasuh anak (mothering ability) dari seekor induk. Oleh karena itu disamping melakukan seleksi induk berdasarkan NP berat badan perlu juga melakukan seleksi terhadap ukuran tubuh terutama pada lebar pinggul (Neser et al., 2012). Pengukuran ternak di BPTU-HPT sapi Aceh Indrapuri hanya meliputi tinggi gumba, panjang badan, dan lingkar dada sehingga perlu melakukan pengukuran lebar pinggul dan tinggi pinggul untuk mengurangi resiko terjadinya dystochia saat melakukan seleksi berdasarkan BL. Berat lahir dengan BS dan BY memiliki nilai korelasi sedang sampai tinggi (Suhada et al., 2009; Karnaen, 2004) sehingga seleksi pada ternak dapat dilakukan dengan cepat melalui BL. Seleksi induk berdasarkan dua catatan individu mempunyai arti ekonomi yang penting karena seleksi tersebut tidak memerlukan banyak pengamatan sehingga menghemat biaya pemeliharaan (Nugent et al., 1991).

\section{Kesimpulan}

Nilai heritabilitas dan repitabilitas $\mathrm{BL}_{\mathrm{T}}$ yang diperoleh masing-masing termasuk kategori sedang dan tinggi dengan keterandalan yang baik. Sifat BL memiliki keragaman genetik yang relatif kecil, sehingga akan menghasilkan peringkat NP yang 
sama pada beberapa pejantan jika digunakan sebagai kriteria seleksi calon pejantan unggul.

\section{Daftar Pustaka}

Anonimus. 2012. Penetapan Rumpun dan Galur Ternak Indonesia Tahun 2010-2011. Direktorat Jendral Peternakan dan Kesehatan Hewan. Jakarta.

Becker, A. 1992. Manual of Quantitative Genetics. $4^{\text {th }}$ ed. Washington State University, Washington.

Chapman, A. B. 1985. General and Quantitative Genetics. Department of Genetics, Meat and Animal Science, and Dairy Science. University of Wisconsin, Madison.

Cunningham, E. P. 1969. Animal Breeding Theory. Institute of Animal Genetics and Breeding, Oslo.

Daly, J. J. 1980. Breeding for Beef Production. Beef Cattle Hosbandry Branch. Queensland Department of Primary Industries. Queensland.

Daniel, L. H. 1980. Population Genetic. Perdue University. Sinauer Associates, Inc. Sunderland, Massachusetts.

Falconer, R. D. and T. F. Mackay. 1996. Introduction to Quantitative Genetics. $4^{\text {th }}$ ed. Department of Genetics. North Canada State University. Prince George.

Gunawan, D. Pamungkas, dan L. Affandhy. 1998. Sapi Bali, Potensi, Produktivitas dan Nilai Ekonomi. Kanisius, Yogyakarta.

Gushairiyanto dan Depison. 2009. Korelasi genetik antara bobot sapih dengan bobot satu tahun dan laju pertumbuhan pasca sapih sapi Brahman Cross. J. Indon. Trop. Anim. Agric. 12: 171-175.

Hammond, K. and W. H. Upton. 1985. Bos Indicus Derived Breeds for Beef Production in the $80_{\text {s. }}$ A Handbook for a National Breeders Forum. The University of New England. Armidale. New South Wales, Australia.

Hardjosubroto, W. 1994. Aplikasi Pemuliabiakan Ternak di Lapangan. Gramedia Widiasarana Indonesia, Jakarta.
Karnaen. 2004. Pendugaan parameter genetik, korelasi genetik dan fenotipik pada sapi Madura. J. Indon. Trop. Anim. Agric. 25: 1224.

Kress, D. D. and P. J. Buferning. 1972. Weaning weight related to subsequent most probable producing ability in Herford cows. J. Anim. Sci. 35: 327-335.

Lasley, J. F. 1978. Genetics of Livestock Improvement. Department of Animal Husbandry. University of Missouri. PrenticeHall, Inc., New Jersey.

Neser, F. W. C., J. B. van Wyk, M. D. Fair, P. Lubout and B. J. Crook. 2012. Estimation of genetic parameters for growth traits in Brangus cattle. S. Afr. J. Anim. Sci. 42: 469473.

Nugent, R. A., D. R. Notter and W. E. Ball. 1991. Body measurements of newborn calves and relationship of calf shape to sire breeding value for birth weight and calving ease. J. Anim. Sci. 69: 2413-2421.

Pattie, W. A. and J. W. James. 1985. Principle of Applied Animal Breeding. Department of Animal Breeding. University of Queensland, Queensland.

Saputra, H. Daryanto, A. dan D. S. Hendrawan. 2011. Strategi pengembangan sapi potong berwawasan agribisnis di provinsi Aceh. Jurnal Manajemen dan Agribisnis 6: 114-118.

Suhada, H., Sumadi, dan N. Ngadiyono. 2008. Estimasi parameter genetik sifat produksi sapi Simmental di Balai Pembibitan Ternak Unggul Sapi Potong Padang Mengatas, Sumatera Barat. Buletin Peternakan 33: 1-7.

Supiyono. 1998. Ilmu Tilik Ternak. Fakultas Peternakan, Universitas Gadjah Mada, Yogyakarta.

Warwick, E. J., J. W. Astuti, dan W. Hardjosubroto. 1990. Pemuliaan Ternak. Gadjah Mada University Press, Yogyakarta.

Yusran, M. A., K. Ma'sum, D. B. Wijono, L. Affandhy, dan A. Rasyid. 1995. Evaluasi nilai pemuliaan calon pejantan donor semen beku sapi Madura melalui uji keturunan. Jurnal Ilmiah Penelitian Ternak Grati 4: 17-23. 